\title{
'Candidatus Phytoplasma brasiliense', a new phytoplasma taxon associated with hibiscus witches' broom disease
}

\author{
1 USDA-ARS, Molecular \\ Plant Pathology \\ Laboratory, Beltsville, \\ MD 20705, USA \\ 2 Programa de Biotecnologia \\ Vegetal/Universidade \\ Federal do Rio de Janeiro \\ (UFRJ) and UFRJ/IB, \\ Departamento de \\ Entomologia e \\ Fitopatologia, Rio de \\ Janeiro, Brazil \\ 3 Ohio Agricultural Research \\ and Development Center, \\ Wooster, USA \\ 4 UFRRJ/IB, Departamento \\ de Entomologia e \\ Fitopatologia, Rio de \\ Janeiro, Brazil
}

\author{
Helena G. Montano, ${ }^{1,2}$ Robert E. Davis, ${ }^{1}$ Ellen L. Dally, ${ }^{1}$ \\ Saskia Hogenhout, ${ }^{3}$ João P. Pimentel ${ }^{4}$ and Paulo S. T. Brioso ${ }^{4}$ \\ Author for correspondence: Robert E. Davis. Tel: +1 301504 5745. Fax: + 13015045449. \\ e-mail:davisr@ba.ars.usda.gov
}

\begin{abstract}
Hibiscus rosa-sinensis is a valuable ornamental species widely planted in Brazil. Many plants are affected by witches' broom disease, which is characterized by excessive axillary branching, abnormally small leaves, and deformed flowers, symptoms that are characteristic of diseases attributed to phytoplasmas. A phytoplasma was detected in diseased Hibiscus by amplification of rRNA operon sequences by PCRs, and was characterized by RFLP and nucleotide sequence analyses of 165 rDNA. The collective RFLP patterns of amplified 165 rDNA differed from the patterns described previously for other phytoplasmas. On the basis of the RFLP patterns, the hibiscus witches' broom phytoplasma was classified in a new 16S rRNA RFLP group, designated group 16SrXV. A phylogenetic analysis of $16 \mathrm{~S}$ rDNA sequences from this and other phytoplasmas identified the hibiscus witches' broom phytoplasma as a member of a distinct subclade (designated subclade xiv) of the class Mollicutes. A phylogenetic tree constructed on the basis of 16S rRNA gene sequences was consistent with the hypothesis that there was divergent evolution of hibiscus witches' broom phytoplasma and its closest relatives (members of 16S rRNA RFLP group 16SrII) from a common ancestor. On the basis of unique properties of the DNA from hibiscus witches' broom phytoplasma, it is proposed that it represents a new taxon, namely 'Candidatus Phytoplasma brasiliense'.
\end{abstract}

Keywords: phytoplasma, classification, 16S rDNA

\section{INTRODUCTION}

Botanical species belonging to the genus Hibiscus are widely distributed in the Brazilian landscape and are employed both as small trees and as shrubs (Penna, 1983; Blossfeld, 1984). However, a disease attributed to a phytoplasma has become a major problem in Hibiscus culture. In Brazil, witches' broom disease of Hibiscus was first reported in São Paulo State in plants of Hibiscus rosa-sinensis L. The disease was characterized by symptoms of witches' broom, i.e. leaf yellowing and malformation, as well as by short internodes (Vicente et al., 1974). Later, the disease was

\footnotetext{
Abbreviations: $A Y$, aster yellows; $C X$, Canadian peach $X$; $C Y E(=C Y E-C)$, clover yellow edge; EY, elm yellows; PPWB, pigeon pea witches' broom; PWB, potato witches' broom; SPWB, sweet potato witches' broom.

The GenBank accession number for the phytoplasma strain HibWB26 sequence determined in this study is AF147708.
}

observed, in the State of Rio de Janeiro, in plants of the same species; they displayed similar symptoms and premature dropping of flowers (Davis, 1995; Kitajima, 1994; Kitajima et al., 1984). The disease has also been observed in naturally infected plants of $H$.rosa-sinensis in Brasília, Distrito Federal (P. S. T. Brioso, unpublished). In Australia, an unidentified phytoplasma has been reported to be associated with a witches' broom disease of Hibiscus heterophyllus, an Australian native species that is also grown commercially (Hiruki, 1987).

In the present study, we investigated a phytoplasma associated with hibiscus witches' broom disease in Brazil (Montano \& Brioso, 1997). The results have defined the relationship between this phytoplasma and phytoplasmas representing 'Candidatus Phytoplasma species' and putative species worldwide. In this communication, we report results from the amplification of rRNA operon sequences from hibiscus witches' broom 
phytoplasma templates by the use of phytoplasmaspecific PCRs and the cloning and analysis of amplified DNA. The results include RFLP analyses of $16 \mathrm{~S}$ rDNA and interpretation of the findings in the context of a revised classification scheme (Lee et al., 1998) that contains 14 16S rRNA gene groups, each of which represents at least one putative Phytoplasma species (Gundersen et al., 1994). We also report, for the first time, the nucleotide sequence of a segment of the hibiscus witches' broom phytoplasma rRNA operon, and describe sequences that are unique in this phytoplasma. Our data led us to propose that the hibiscus witches' broom phytoplasma is taxonomically unique among known phytoplasmas.

\section{METHODS}

Plant samples and reference phytoplasma strains. Symptomatic leaves of $H$. rosa-sinensis L. (Malvaceae) were collected in the state of Rio de Janeiro from two naturally infected plants showing witches' broom symptoms. Reference phytoplasma strains representing various $16 \mathrm{~S}$ rDNA RFLP groups were used in direct comparisons of RFLP patterns obtained in this study. These references and their 16S rRNA group affiliations were as follows: aster yellows (AY; group 16SrI), sweet potato witches' broom (SPWB; group 16SrII), Canadian peach X (CX; group 16SrIII), clover yellow edge $(\mathrm{CYE}=\mathrm{CYE}-\mathrm{C})$ from Canada (group 16SrIII), elm yellows (EY; group 16SrV), potato witches' broom (PWB; group 16SrVI) and pigeon pea witches' broom (PPWB; group 16SrIX) phytoplasmas. Group affiliations are designated according to the classification system of Lee et al. (1998). Phytoplasmas AY, SPWB, CX, CYE-C, EY, PWB and PPWB were maintained by graft transmission in plants of periwinkle [Catharanthus roseus (L.) G.Don] maintained in a greenhouse.

Nucleic acid extraction and PCR. Leaf midribs or whole small leaves $(1 \mathrm{~g})$ were excised from diseased plants of $H$. rosasinensis. DNA was extracted according to Montano et al. (2000) for Hibiscus and according to Davis et al. (1997) for periwinkle. Nested PCRs primed by phytoplasma universal

Table 1. GenBank accession numbers of phytoplasmal $16 \mathrm{~S}$ rRNA gene sequences used in this study

\begin{tabular}{|c|c|c|}
\hline Phytoplasma & Accession no. & Reference \\
\hline Hibiscus witches' broom (HibWB26) & AF147708 & This paper \\
\hline Michigan aster yellows (MIAY) & M30970 & Lim \& Sears (1989) \\
\hline Peanut witches' broom (PnWB) & L33765 & Gundersen et al. (1994) \\
\hline Sweet potato witches' broom (SPWB) & L33770 & Gundersen et al. (1994) \\
\hline Sunn hemp witches' broom (SUNHP) & X76433 & Schneider et al. (1995a) \\
\hline $\begin{array}{l}\text { Witches' broom disease of lime (WBDL) } \\
\text { ('Candidatus Phytoplasma aurantifolia') }\end{array}$ & U15442 & Zreik et al. (1995) \\
\hline Faba bean phyllody (FBP) & X83432 & Schneider et al. (1995a) \\
\hline Sweet potato little leaf (SPLL) & X90591 & Padovan et al. (1996) \\
\hline Italian alfalfa witches' broom (IAWB) & Y16390 & Seemüller et al. (1998) \\
\hline Picris echioides phyllody (PEP) & Y16393 & Seemüller et al. (1998) \\
\hline Papaya mosaic (PpM) ('Candidatus Phytoplasma australasia') & Y10096 & White et al. (1998) \\
\hline $\begin{array}{l}\text { Papaya yellow crinkle (PpYC) } \\
\text { ('Candidatus Phytoplasma australasia') }\end{array}$ & Y10097 & White et al. (1998) \\
\hline Western X-disease (WX) & L04682 & Seemüller et al. (1994) \\
\hline Canada peach $\mathrm{X}$-disease $(\mathrm{CX})^{*}$ & L33733 & Gundersen et al. (1994) \\
\hline Clover yellow edge, Canada $(\mathrm{CYE}=\mathrm{CYE}-\mathrm{C})$ & AF175304 & Staniulis et al. (2000) \\
\hline Chayote witches' broom [ChWBIII(Ch10)] & AF147706 & Montano et al. (2000) \\
\hline Chayote witches' broom [ChWBIII(Mor5)] & AF147707 & Montano et al. (2000) \\
\hline Coconut lethal yellows (LY) & U18747 & Tymon et al. (1998) \\
\hline Tanzanian coconut lethal disease (LD) & X80117 & Tymon et al. (1998) \\
\hline Elm yellows (EY1) & AF189214 & Unpublished \\
\hline Clover proliferation $(\mathrm{CP})^{*}$ & L33761 & Gundersen et al. (1994) \\
\hline Ash yellows (AshY1) ('Candidatus Phytoplasma fraxini') & AF189215 & Unpublished \\
\hline Loofah witches' broom (LfWB) & L33764 & Gundersen et al. (1994) \\
\hline Pigeon pea witches' broom (PPWB) & U18763 & Unpublished \\
\hline Apple proliferation (AT) & X68375 & Seemüller et al. (1994) \\
\hline Rice yellow dwarf (RYD) & D12581 & Namba et al. (1993) \\
\hline $\begin{array}{l}\text { Australian grapevine yellows (AUSGY) } \\
\text { ('Candidatus Phytoplasma australiense') }\end{array}$ & L76865 & Davis et al. (1997) \\
\hline Stolbur (STOL) & X76427 & Seemüller et al. (1994) \\
\hline Acholeplasma laidlawii & M23932 & Weisburg et al. (1989) \\
\hline
\end{tabular}

* For analyses in the present work, sequences L33733 and L33761 were modified by insertion of corrected bases in place of n characters in the original GenBank sequences, and sequence L33733 was modified by correction of base assignments in positions 633 and $676-679$ (R. E. Davis \& E. L. Dally, unpublished). 


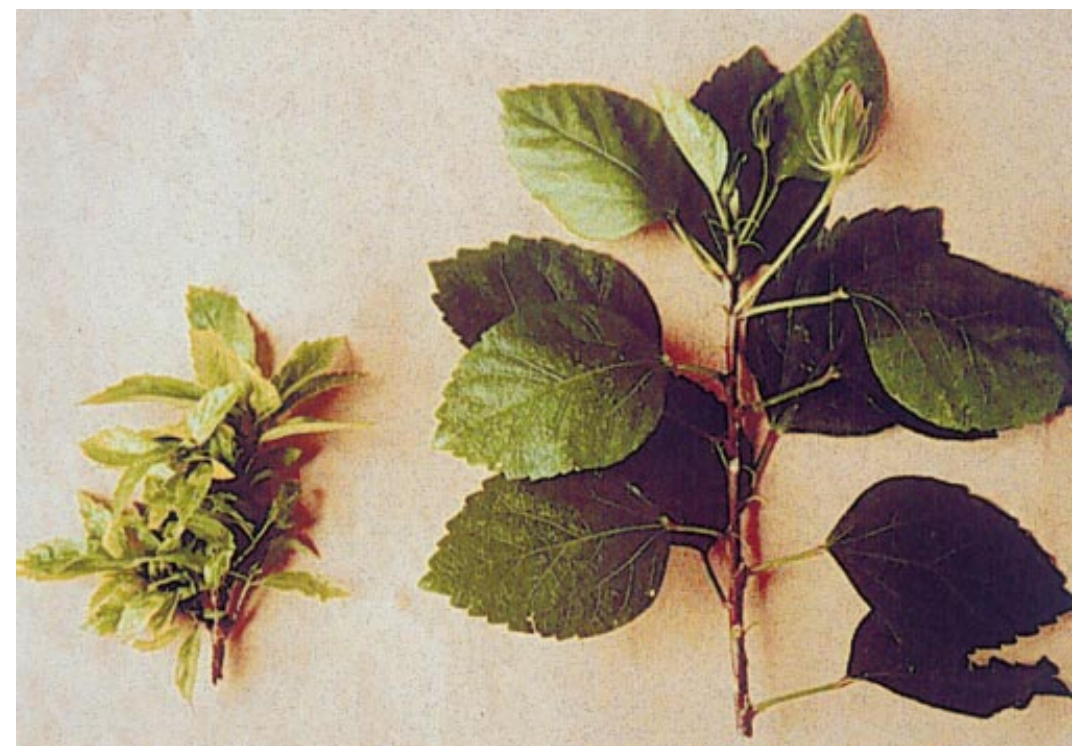

Fig. 1. Left: naturally infected Hibiscus rosasinensis exhibiting symptoms of witches' broom. Right: H. rosa-sinensis showing no symptoms of disease.

primer pairs P1/P7 (Deng \& Hiruki, 1991; Schneider et al., 1995b) and F2n/R2 (Gundersen \& Lee, 1996) were carried out according to Jomantiene et al. (1998a).

RFLP analyses of amplified phytoplasma DNA. Products from nested PCRs primed by R16F2n/R2 were analysed by single restriction endonuclease digestion with $A l u \mathrm{I}, H h a \mathrm{I}$ and $K p n \mathrm{I}$ (Life Technologies) and BfaI, DraI, HaeIII, HinfI, HpaI, HpaII, MseI, RsaI, Sau3AI and TaqI (New England Biolabs) according to the instructions of the manufacturers. The products of digestion were analysed by electrophoresis through a $5 \%$ polyacrylamide gel, followed by staining with ethidium bromide and visualization of DNA bands with a UV transilluminator. The DNA fragment size standard used was PhiX174 RF HaeIII digest (Life Technologies). The RFLP patterns of phytoplasma DNAs were compared with previously published RFLP patterns (Davis et al., 1997, 1998; Jomantiene et al., 1998a, b; Lee et al., 1993, 1998; Montano et al., 2000).

Cloning of PCR products and sequencing of DNA. A phytoplasma DNA sequence that had been amplified in a PCR primed by $\mathrm{P} 1 / \mathrm{P} 7$ was cloned in Escherichia coli by using the TOPO TA cloning kit (Invitrogen) according to the manufacturer's instructions. The cloned $1.8 \mathrm{~kb}$ DNA fragment was sequenced by automated DNA sequencing. The sequence was assembled after a minimum of $2 \times$ sequencing coverage for each base position. The GenBank accession number for the nucleotide sequence determined in this study is AF147708 (Table 1).

Nucleotide sequence accession numbers. The GenBank accession numbers of the DNA sequences from hibiscus witches' broom phytoplasma, 27 phytoplasma strains representing 12 16S rRNA phytoplasma groups, and Acholeplasma laidlawii used in this study are listed in Table 1.

Sequence similarity, similarity coefficient calculations and putative restriction site analysis. Alignments of sequences were generated and sequence similarities evaluated by using the DNASTAR program ALIGN option (DNASTAR). Putative restriction site maps were generated by using the DNASTAR program MAPDRAW option. Similarity coefficients $(F)$ be- tween the 16S rDNA of hibiscus witches' broom phytoplasma and the 16S rDNAs of other phytoplasmas were calculated according to Nei \& Li (1979) on the basis of putative restriction site maps. $F$ was calculated as $F=$ $2 N_{x y} /\left(N_{x}+N_{y}\right)$, where $x$ and $y$ are the strains of two given phytoplasmas, $N_{x}$ and $N_{y}$ are the numbers of fragments resulting from digestion by 10 enzymes in strains $x$ and $y$, respectively, and $N_{x y}$ is the number of fragments shared by the two strains.

Phylogenetic analysis. The $16 \mathrm{~S}$ rRNA gene sequences $(1 \cdot 2 \mathrm{~kb}$ in size) from hibiscus witches' broom phytoplasma (strain HibWB26), 20 phytoplasma strains representing $1116 \mathrm{~S}$ rRNA phytoplasma groups, and A. laidlawii were aligned using CLUSTAL $\mathrm{x}$ version 1.63b (Thompson et al., 1997) and DNASTAR. Gaps and incomplete sequences were removed. Analyses were performed with the computer program CLUSTAL $\mathrm{X}$. Phylogenetic trees were constructed by the neighbour-joining method and the tree was viewed by using TREEVIEWPPC (Page, 1996). A. laidlawii was selected as the outgroup to root the tree. Bootstrapping was performed 1000 times for estimation of stability and support for the clades.

\section{RESULTS}

\section{Detection and classification of phytoplasma in naturally diseased Hibiscus}

The diseased Hibiscus plants exhibited symptoms including witches' broom, leaf yellowing, malformation and reduced size of leaves, as well as short internodes and proliferation of axillary shoots (Fig. 1). Amplification of phytoplasmal 16S rDNA in nested PCRs primed by phytoplasma universal primer pairs indicated that both of the diseased Hibiscus plants, designated plants 24 and 26, respectively, were infected by phytoplasmas (data not shown). These results are consistent with preliminary reports of phytoplasma detection in diseased Hibiscus plants in Brazil (Barros et al., 1997, 1998; Montano \& Brioso, 1997). The 
(a)

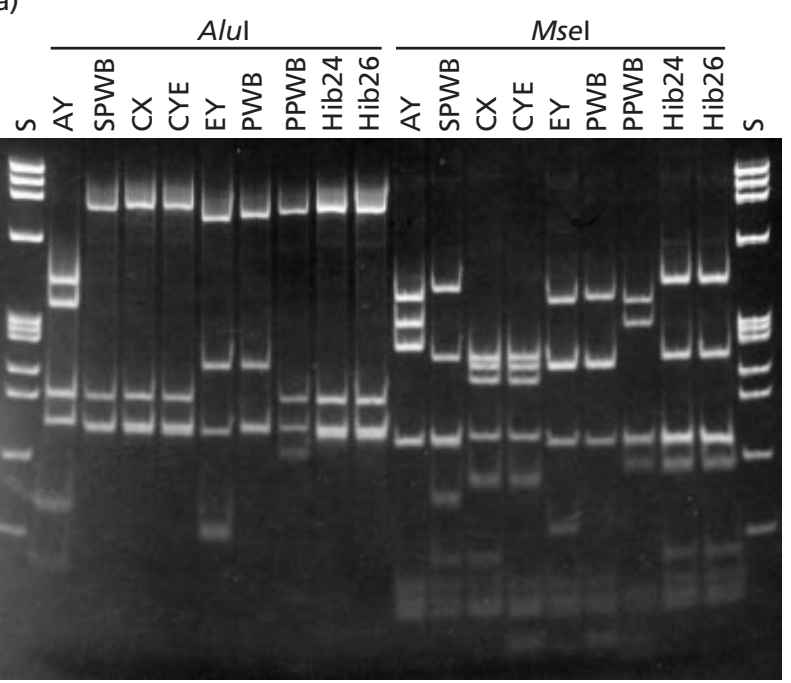

(b)

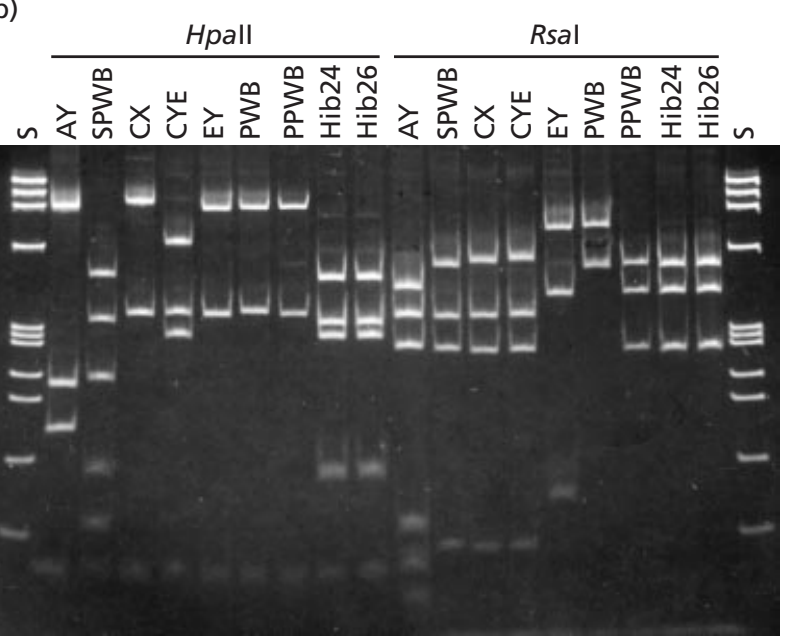

Fig. 2. RFLP analysis of $16 \mathrm{~S}$ rDNAs amplified in PCRs from naturally diseased plants of $H$. rosa-sinensis in Brazil. The first PCR was primed by primer pair P1/P7, and this was followed by reamplification of target DNA in a nested PCR primed by primer pair F2n/R2. Lane S: fragment size standard, PhiX174 RFI DNA Haelll digest. Lanes AY, SPWB, CX, CYE, EY, PWB, PPWB: digests of DNAs from the reference phytoplasmas [aster yellows (AY), sweet potato witches' broom (SPWB), Canada X-disease (CX), clover yellow edge $(C Y E=C Y E-C)$, elm yellows $(E Y)$, potato witches' broom (PWB) strain of clover proliferation phytoplasma, and pigeon pea witches' broom (PPWB)]. Hib24 and Hib26: digests of DNAs amplified from diseased plants of $H$. rosa-sinensis. (a) RFLP patterns after digestion with Alul and Msel. (b) RFLP patterns after digestion with Hpall and Rsal.

phytoplasma strains detected in plants 24 and 26 were designated strains HibWB24 and HibWB26, respectively.

Initially, strains HibWB24 and HibWB26 were characterized by RFLP analysis using four restriction enzymes (Fig. 2). The HibWB phytoplasma strains could not be distinguished from one another on the basis of AluI, MseI, HpaII and RsaI RFLP patterns of the 16S rDNAs. The AluI RFLP pattern of $16 \mathrm{~S}$ rDNA from the strains was very similar to the patterns of DNA from the CX and CYE (both of which are members of group 16SrIII) and SPWB (a member of group 16SrII) phytoplasmas but differed from the RFLP patterns of DNA from AY (group 16SrI), EY (group 16SrV), PWB (group 16SrVI) and PPWB (group 16SrIX) phytoplasmas (Fig. 2a). However, MseI and HpaII RFLP patterns of $16 \mathrm{~S}$ rDNA from HibWB24 and HibWB26 differed from those of all reference phytoplasmas used in this study (Fig. 2, Table 2). The MseI and HpaII RFLP patterns of $16 \mathrm{~S}$ rDNA from the HibWB phytoplasma strains were unique and have not been reported previously (Lee et al., 1993, 1998; Davis et al., 1997, 1998; Jomantiene et al., 1998a, b; Montano et al., 2000) for any phytoplasma. The RsaI RFLP pattern from HibWB24 and HibWB26 was indistinguishable from the pattern of 16S rDNA from PPWB (Fig. 2b).

Both strains were further characterized by RFLP analysis using an additional nine restriction enzymes, including BfaI, DraI, HaeIII, HhaI, Sau3AI, TaqI, HinfI, HpaI and KpnI. HibWB24 and HibWB26 were not distinguished from one another on the basis of RFLP patterns (Table 2). Fig. 3 shows the BfaI, DraI, HaeIII, HhaI, Sau3AI and TaqI RFLP patterns of DNA from strain HibWB26. RFLP patterns from the use of HinfI, HpaI and KpnI are not shown. A summary of all pattern groups produced by RFLP analysis of $16 \mathrm{~S}$ rDNA from hibiscus witches' broom phytoplasma strains HibWB24 and HibWB26 is presented in Table 2 . The two strains were mutually indistinguishable on the basis of collective RFLP patterns of 16S rDNA. Although the hibiscus witches' broom phytoplasma strains appeared to be similar in

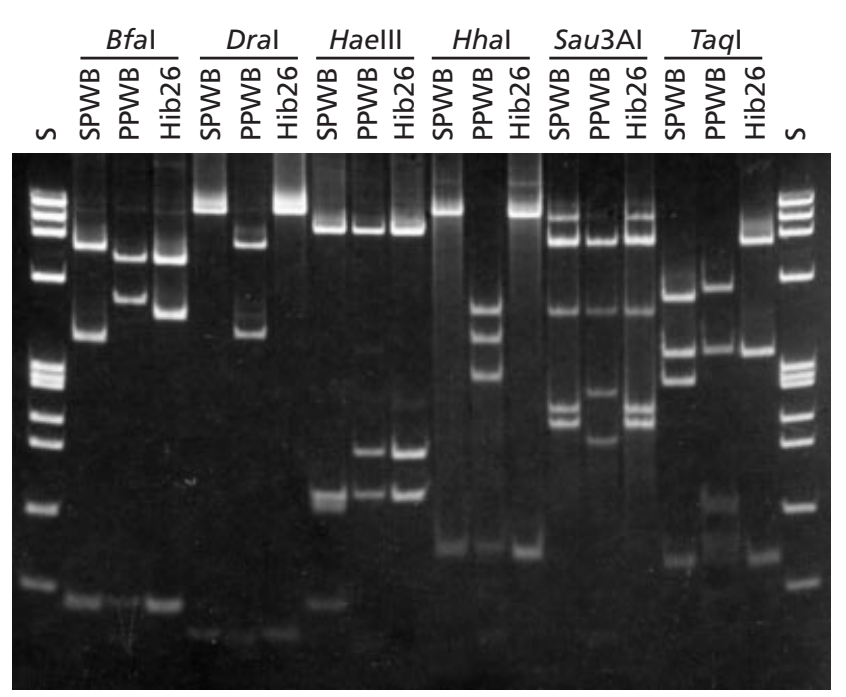

Fig. 3. RFLP analysis of $16 \mathrm{~S}$ rDNAs amplified in nested PCRs from two reference phytoplasma strains and strain HibWB26 from $H$. rosa-sinensis after digestion with Bfal, Dral, Haelll, Hhal, Sau3Al and Taql. Abbreviations are the same as for Fig. 1. 
Table 2. Summary of pattern groups produced by enzymic RFLP analysis of 16S rDNA from strains of hibiscus witches' broom and reference phytoplasmas

Strain abbreviations are as shown in Table 1. Designations of phytoplasma group and subgroup affiliations are according to Lee et al. (1998). I, II, III, V, VI, IX are 16S rRNA groups. Subgroups are in parentheses. Hibiscus witches' broom phytoplasma strains are the only known members of group $16 \mathrm{SrXV}$ and are placed in subgroup A. Groups $16 \mathrm{SrII}$ and $16 \mathrm{SrIX}$ were included because RFLP patterns of 16S rDNA from hibiscus witches' broom phytoplasma appeared to be most similar to these phytoplasmas. Group 16SrIII strains were included because of the recent description of group 16SrIII phytoplasma strains [ChWBIII(Mor5) and ChWBIII(Ch10)] in Brazil (Montano et al., 2000). Groups 16SrI, 16SrV and 16SrVI were included for comparisons. Each RFLP pattern number represents a specific pattern obtained by using a given restriction endonuclease. The numbers are according to the system of Lee et al. (1998). Numbers in bold indicate RFLP patterns determined in this study. Italicized numbers indicate RFLP patterns not previously described. The remaining numbers are from Lee et al. (1998) and Montano et al. (2000).

\begin{tabular}{|c|c|c|c|c|c|c|c|c|c|c|c|c|c|}
\hline \multirow{2}{*}{$\begin{array}{l}\text { Phytoplasma } \\
\text { strain }\end{array}$} & \multirow{2}{*}{$\begin{array}{c}\text { 16S rRNA } \\
\text { group } \\
\text { (subgroup) }\end{array}$} & \multicolumn{12}{|c|}{ RFLP pattern obtained with the restriction endonuclease indicated } \\
\hline & & MseI & AluI & BfaI & HhaI & HpaI & HpaII & Sau3AI & TaqI & RsaI & DraI & HaeIII & HinfI \\
\hline HibWB24 & $\mathbf{X V}(\mathbf{A})$ & 28 & 4 & 2 & 3 & 1 & 10 & 2 & 1 & 4 & 1 & 6 & 2 \\
\hline HibWB26 & $\mathbf{X V}(\mathrm{A})$ & 28 & 4 & 2 & 3 & 1 & 10 & 2 & 1 & 4 & 1 & 6 & 2 \\
\hline AY & $\mathrm{I}(\mathrm{B})$ & 1 & 1 & 2 & 2 & 1 & 1 & 1 & 1 & 1 & 1 & 1 & 1 \\
\hline PnWB & $\mathrm{II}(\mathrm{A})$ & 6 & 4 & 3 & 3 & 1 & 3 & 2 & 2 & 2 & 1 & 3 & 2 \\
\hline SPWB & II(A) & 6 & 4 & 3 & 3 & 1 & 3 & 2 & 2 & 2 & 1 & 3 & 2 \\
\hline WBDL & $\mathrm{II}(\mathrm{B})$ & 7 & 4 & 3 & 3 & 1 & 4 & 2 & 1 & 2 & 1 & 3 & 2 \\
\hline FBP & $\mathrm{II}(\mathrm{C})$ & 7 & 4 & 3 & 3 & 1 & 3 & 2 & 1 & 2 & 1 & 3 & 2 \\
\hline SPLL & II(D) & 6 & 5 & - & - & - & 3 & - & - & 2 & - & - & - \\
\hline $\mathrm{CX}$ & III(A) & 8 & 6 & 1 & 1 & 1 & 5 & 3 & 1 & 2 & 1 & 4 & 2 \\
\hline CYE-C & III(B) & 9 & 6 & 1 & 1 & 1 & 6 & 4 & 1 & 2 & 1 & 4 & 2 \\
\hline ChWBIII(Ch10) & $\operatorname{III}(\mathrm{J})$ & 9 & 6 & 1 & 4 & 1 & 6 & 4 & 1 & 2 & - & 4 & 2 \\
\hline ChWBIII(Mor5) & $\mathrm{III}(\mathrm{J})$ & 9 & 6 & 1 & 4 & 1 & 6 & 4 & 1 & 2 & - & 4 & 2 \\
\hline EY & $\mathrm{V}(\mathrm{A})$ & 14 & 9 & 1 & 2 & 1 & 7 & 4 & 1 & 5 & 1 & 5 & 2 \\
\hline PWB & $\mathrm{VI}(\mathrm{A})$ & 15 & 10 & 1 & 7 & 1 & 7 & 4 & 1 & 6 & 1 & 5 & 2 \\
\hline PPWB & IX(A) & 17 & 12 & 1 & 9 & 1 & 7 & 4 & 4 & 4 & 2 & 6 & 4 \\
\hline
\end{tabular}

terms of some RFLP patterns to members of group 16SrII (peanut witches' broom phytoplasma group) and to PPWB, both strains were distinguished from all group 16SrII phytoplasmas and PPWB on the basis of collective RFLP patterns. The collective RFLP patterns of amplified 16S rDNA from the hibiscus witches' broom phytoplasma strains also differed from the patterns described previously for other phytoplasmas. On the basis of the RFLP patterns, the hibiscus witches' broom phytoplasma was classified in a new group, designated group $16 \mathrm{SrXV}$. As the collective RFLP patterns indicated that the phytoplasma strains from diseased Hibiscus were mutually indistinguishable, strain HibWB26 was selected as being representative, and was used for further analysis.

\section{Nucleotide sequence similarities}

Sequence similarities between the $1.2 \mathrm{~kb}$ sequences of 16S rDNA (equivalent to fragments amplified in PCRs primed by R16F2n/R16R2) from the HibWB phytoplasma and phytoplasmas affiliated with group 16SrII, group 16SrIII (subgroups III-A and III-J) and group 16SrIX (PPWB phytoplasma) were determined. Strains in group 16SrII and the PPWB phytoplasma were included because RFLP patterns of $16 \mathrm{~S}$ rDNA from hibiscus witches' broom phytoplasma appeared to be most similar to these phytoplasmas. Group 16SrIII strains were included because of the recent description of group 16SrIII phytoplasma strains [ChWBIII(Mor5) and ChWBIII(Ch10)] in Brazil (Montano et al., 2000).

Sequence similarities between 16S rDNA from hibiscus witches' broom phytoplasma and phytoplasmas within group 16SrII ranged from $94.4 \%$ (between HibWB26 and SPLL phytoplasma) to $96.4 \%$ (between HibWB26 and PpYC and PpM phytoplasmas). The sequence similarities between the $16 \mathrm{~S}$ rDNAs of hibiscus witches' broom phytoplasma and WX, ChWBIII(Mor5) and ChWBIII(Ch10) phytoplasmas (members of group 16SrIII) were $88 \cdot 8,89 \cdot 0$ and $89 \cdot 2 \%$, respectively. The sequence similarity between the $16 \mathrm{~S}$ rDNAs of HibWB phytoplasma and PPWB was $87 \%$. The sequence similarities between the $16 \mathrm{~S}$ rDNAs of hibiscus witches' broom phytoplasma and two phytoplasmas, pichris echioides phyllody (PEP) and Italian alfalfa witches' broom (IAWB) phytoplasmas, which are phylogenetically closely related to the group $16 \mathrm{SrII}$ phytoplasmas (Seemüller et al., 1998) but which have not been classified in the 16S rRNA grouping system of Lee et al. (1998), were 96.4 and $96.2 \%$, respectively. 

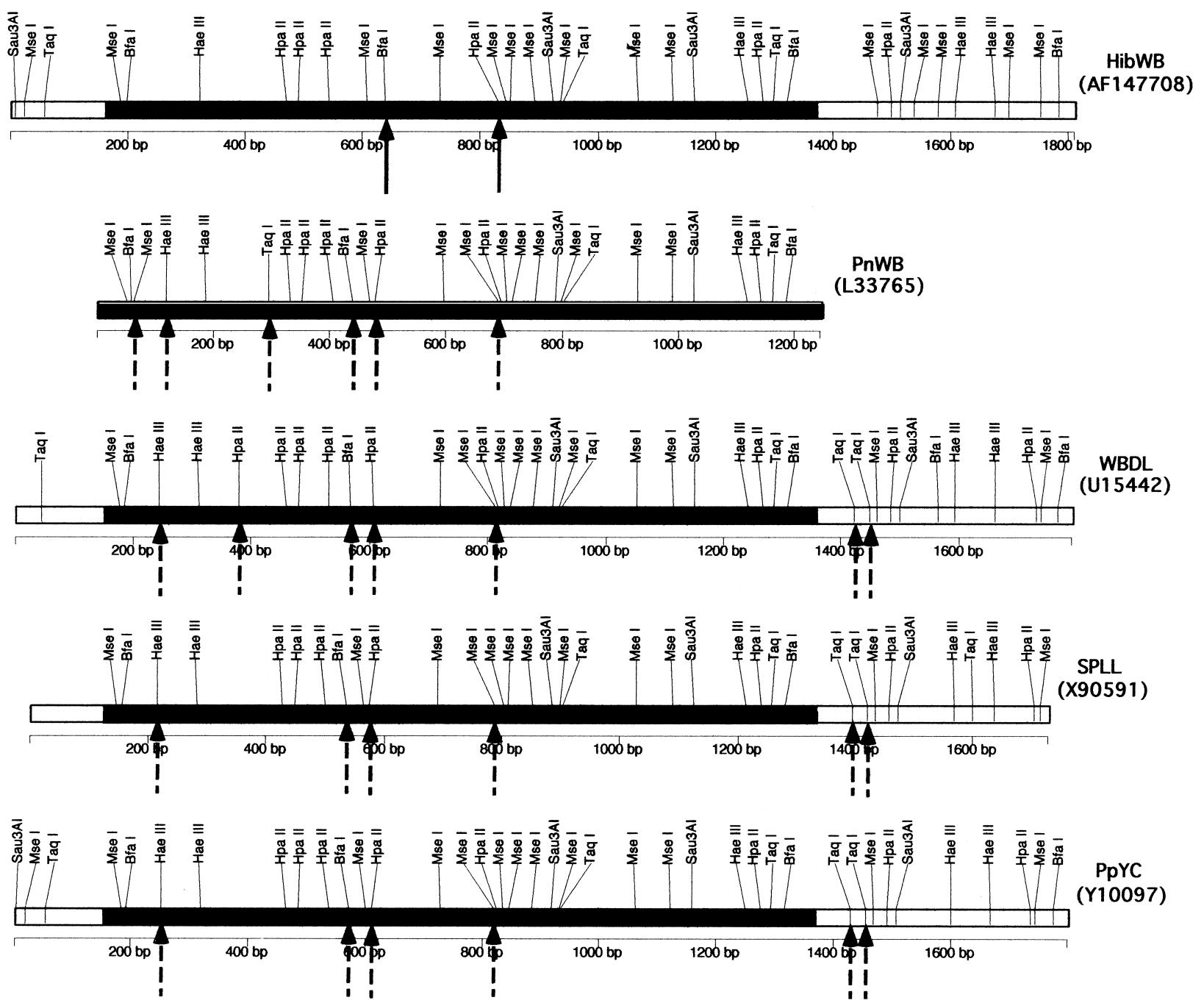

Fig. 4. Analysis of putative restriction sites in rRNA operon sequences from hibiscus witches' broom phytoplasma and phytoplasmas belonging to group 16Srll (the peanut witches' broom phytoplasma group). Maps were generated using the MAPDRAW option of the DNASTAR program (DNASTAR) and manually aligned for comparison of recognition sites for restriction nucleases. HibWB, hibiscus witches' broom phytoplasma from naturally infected $H$. rosa-sinensis in Brazil; PnWB, peanut witches' broom phytoplasma; WBDL, witches' broom disease of lime phytoplasma ('Candidatus Phytoplasma aurantifolia'); SPLL, sweet potato little leaf phytoplasma; PpYC, papaya yellow crinkle phytoplasma ('Candidatus Phytoplasma australasia'). GenBank numbers are given in parentheses. The black region represents the 16S rDNA segment amplified in PCR primed by primer pair F2n/R2. Arrows indicate restriction sites that differentiate HibWB phytoplasma from the reference phytoplasmas. Solid arrows indicate sites present in HibWB phytoplasma 16S rDNA that are absent in the 16S rDNA of one or more phytoplasmas in group 16Srll; broken arrows indicate sites present in the $16 \mathrm{~S}$ rDNA of group 16Srll phytoplasmas that are absent in the 16S rDNA of the HibWB phytoplasma. Additional sites, not indicated by arrows, that distinguish the HibWB phytoplasma from group 16Srll phytoplasmas were located in the 16S-23S rRNA spacer region.

These results indicated that while hibiscus witches' broom phytoplasma (group 16SrXV) may be most closely related to group $16 \mathrm{SrII}$, it is distinct from this and other phytoplasma groups. On the basis of criteria previously proposed by Stackebrandt \& Goebel (1994) for the phylogenetic definition of species - and confirmed by Lee et al. (1998) for phytoplasmas - the range of sequence similarities between the $16 \mathrm{~S}$ rDNAs of HibWB phytoplasma and phytoplasmas in other groups clearly indicated that HibWB phytoplasma may be considered a distinct species.

\section{Putative restriction sites in phytoplasma rRNA operon sequences}

Putative restriction site maps of rRNA operon sequences from phytoplasmas classified in group 16SrII were compared and contrasted with a putative restriction site map of the rRNA operon sequence (GenBank accession no. AF147708) from HibWB phytoplasma. The results of the analysis are illustrated in Fig. 4. The fragment sizes expected on the basis of the analysis of putative restriction sites in the 
'Candidatus Phytoplasma brasiliense'

Table 3. Similarity coefficients derived from RFLPs based on putative restriction site analysis of nucleotide sequences of $16 \mathrm{~S}$ rDNAs of hibiscus witches' broom phytoplasma and other selected phytoplasmas

Abbreviations are as in Table 1.

\begin{tabular}{|c|c|c|c|c|c|c|c|c|c|c|c|c|}
\hline Phytoplasma & $\begin{array}{c}16 \mathrm{~S} \text { rRNA } \\
\text { group affiliation }\end{array}$ & HibWB26 & PnWB & SPWB & WBDL & FBP & SUNHP & SPLL & PpYC & CX & CYE & PPWB \\
\hline HibWB26 & $X V$ & $1 \cdot 00$ & & & & & & & & & & \\
\hline PnWB & II & $0 \cdot 81$ & $1 \cdot 00$ & & & & & & & & & \\
\hline SPWB & II & $0 \cdot 78$ & 0.97 & $1 \cdot 00$ & & & & & & & & \\
\hline WBDL & II & $0 \cdot 77$ & $0 \cdot 88$ & $0 \cdot 87$ & $1 \cdot 00$ & & & & & & & \\
\hline FBP & II & $0 \cdot 80$ & 0.93 & $0 \cdot 92$ & 0.97 & $1 \cdot 00$ & & & & & & \\
\hline SUNHP & II & $0 \cdot 77$ & $1 \cdot 00$ & 0.97 & $0 \cdot 88$ & 0.93 & $1 \cdot 00$ & & & & & \\
\hline SPLL & II & $0 \cdot 82$ & $0 \cdot 91$ & $0 \cdot 88$ & $0 \cdot 91$ & $0 \cdot 94$ & $0 \cdot 91$ & $1 \cdot 00$ & & & & \\
\hline PpYC & II & $0 \cdot 85$ & 0.94 & 0.91 & $0 \cdot 90$ & $0 \cdot 97$ & 0.92 & 0.97 & $1 \cdot 00$ & & & \\
\hline $\mathrm{CX}$ & III & $0 \cdot 55$ & $0 \cdot 53$ & $0 \cdot 54$ & $0 \cdot 48$ & $0 \cdot 55$ & $0 \cdot 53$ & $0 \cdot 59$ & $0 \cdot 59$ & $1 \cdot 00$ & & \\
\hline CYE & III & $0 \cdot 58$ & $0 \cdot 50$ & $0 \cdot 51$ & $0 \cdot 50$ & $0 \cdot 54$ & $0 \cdot 50$ & $0 \cdot 63$ & $0 \cdot 60$ & $0 \cdot 88$ & $1 \cdot 00$ & \\
\hline PPWB & IX & $0 \cdot 59$ & $0 \cdot 49$ & $0 \cdot 50$ & $0 \cdot 44$ & $0 \cdot 49$ & $0 \cdot 50$ & $0 \cdot 49$ & $0 \cdot 48$ & 0.53 & $0 \cdot 55$ & $1 \cdot 00$ \\
\hline
\end{tabular}

sequenced HibWB phytoplasma DNA were in excellent agreement with the fragment sizes obtained by enzymic RFLP analysis of amplified DNA. HibWB phytoplasma was distinguished by the presence, in sequence AF 147708, of a $B f a I$ site that is absent in the $16 \mathrm{~S}$ rDNA of all group 16SrII phytoplasmas mapped, and by the presence of an HpaII site that is absent in sweet potato little leaf phytoplasma $16 \mathrm{~S}$ rDNA. HibWB phytoplasma was further distinguished by the absence, in HibWB rDNA, of several putative restriction sites that are present in rRNA operon sequences of the group 16SrII phytoplasmas.

\section{Similarity coefficients}

Similarity coefficients derived from RFLPs were calculated on the basis of putative restriction site analyses of nucleotide sequences of $16 \mathrm{~S}$ rDNA (Table 3). Hibiscus witches' broom phytoplasma $16 \mathrm{~S}$ rDNA was compared with that of phytoplasmas from 16S rRNA groups that were included in the analysis of sequence similarities described above. Examination of Table 3 as a whole reveals that coefficients of similarity among members of the same $16 \mathrm{~S}$ rRNA RFLP group, for example group 16SrII, are no less than 0.87 . The coefficient of similarity between the $16 \mathrm{~S}$ rDNAs of strains CX and CYE in group 16SrIII is 0.88 . The coefficients of similarity for $16 \mathrm{~S}$ rDNAs between HibWB26 and 10 phytoplasma strains belonging to groups 16SrII, 16SrIII and 16SrIX ranged from 0.55 (between the HibWB26 and CX phytoplasmas) to 0.85 (between the HibWB26 and PpYC phytoplasmas). The coefficients of similarity for $16 \mathrm{~S}$ rDNAs between HibWB and strains classified in group 16SrII ranged from 0.77 to $0 \cdot 85$. These results clearly distinguished HibWB phytoplasma from phytoplasmas of group 16SrIII (represented by CX and CYE phytoplasmas) and group 16SrIX, as well as from phytoplasmas classified in group 16SrII. The findings support rec- ognition of the HibWB phytoplasma as representative of a new $16 \mathrm{~S}$ rRNA gene group, $16 \mathrm{SrXV}$, as designated above.

\section{Phylogenetic analysis}

Phylogenetic analysis of 21 phytoplasmas and $A$. laidlawii yielded the tree illustrated in Fig. 5. Strains from phytoplasmas belonging to 11 16S rRNA RFLP groups were included for comparison with the hibiscus witches' broom (HibWB26) phytoplasma. The bootstrapping values strongly supported most branches (Fig. 5), indicating a robust tree whose branching order is in good agreement with previous findings (Gundersen et al., 1994; Seemüller et al., 1994; Davis et al., 1997; White et al., 1998). However, the hibiscus witches' broom (HibWB26) phytoplasma gives rise to a new branch, designated subclade xiv (Fig. 5). This subclade designation builds upon previously published phylogenetic analyses in which 13 phytoplasma subclades were specified (Lee et al., 1998). Although it is most closely related to peanut witches' broom and related phytoplasmas, it is evident that hibiscus witches' broom phytoplasma represents a new lineage.

\section{Sequences unique to phytoplasmas in the 16S rRNA gene of hibiscus witches' broom phytoplasma, strain HibWB26}

The 16S rRNA gene sequence from the HibWB phytoplasma was aligned with sequences from 24 other phytoplasmas that represented the $1216 \mathrm{~S}$ rRNA RFLP groups for which sequences were available. This analysis revealed that the HibWB phytoplasma contains sequences unique to phytoplasmas and sequences that distinguish the HibWB phytoplasma from other phytoplasmas. Seven sequences previously reported to be unique to phytoplasmas (Gundersen et al., 1994; 


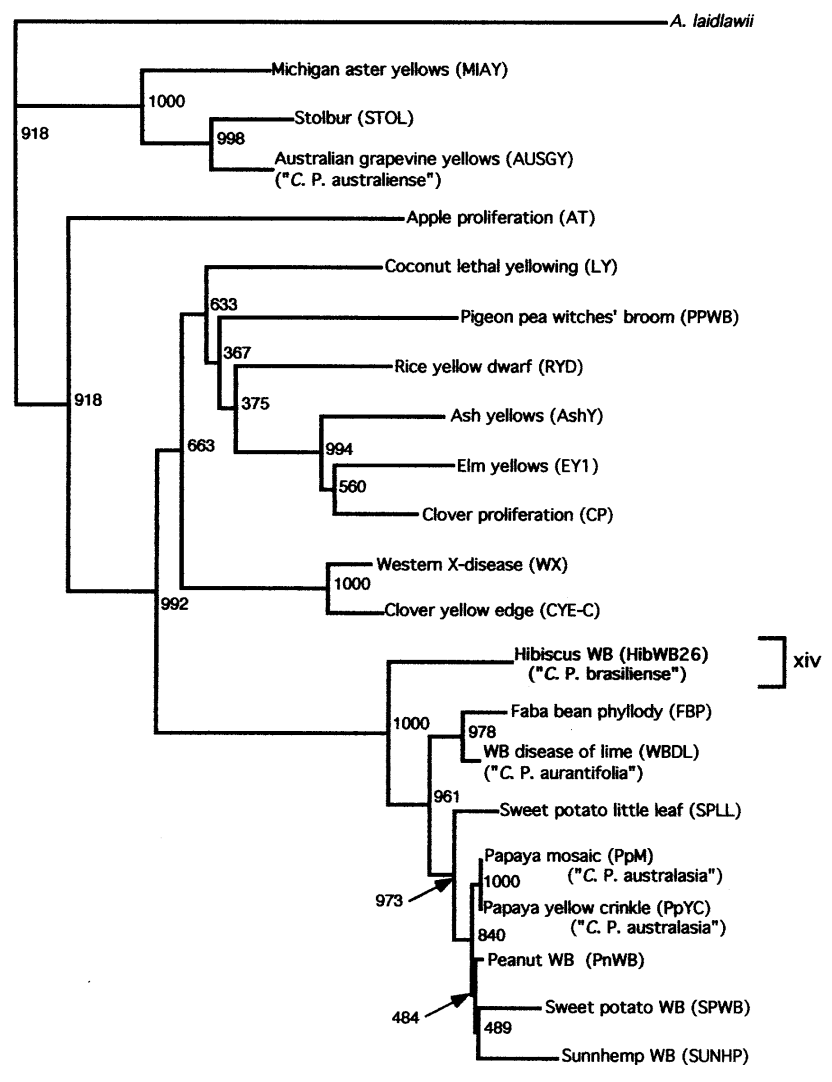

Fig. 5. Phylogenetic tree constructed using the neighbourjoining method with 165 rRNA gene sequences from 21 phytoplasmas and Acholeplasma laidlawii, employing $A$. laidlawii as the outgroup. The branch lengths are proportional to the numbers of inferred character state transformations. The numbers on the branches are bootstrap (confidence) values. Phylogenetic subclade xiv (identified in this study) is indicated. WB, witches' broom. Other abbreviations are the same as in Table 1.

Davis et al., 1997), i.e. ACUGGA at positions corresponding to 153-158 in sequence AF147708, UUUUAAAAG at positions 185-193, GUGU at positions 274-277, UGGAGG at positions 365-370, AUCAG at positions 1011-1015, UAGC at positions 1233-1236 and AGUU at positions 1310-1313, were found in the 16S rRNA of the HibWB phytoplasma. The GGCAAG sequence (corresponding to positions 651-656 in the AF147708 sequence) - another sequence unique to phytoplasmas (Gundersen et al., 1994) - has G at position 654 in the $16 \mathrm{~S}$ rRNA of the HibWB phytoplasma and at the corresponding position in the 16S rRNA of phytoplasmas classified in group 16SrII.

Five sequences were present only in the 16S rDNA of the HibWB phytoplasma and distinguished this organism from other phytoplasmas. The sequence 5'CAG-3' at positions 575-577 of the HibWB DNA (AF147708) differed at two to three positions from corresponding sequences from phytoplasmas in other subclades, and the sequence 5'-ACTTTG-3' at positions 630-635 differed from the sequences in other phytoplasmas at three to five positions. The sequence 5'-GAAAAAGAAAG-3' at positions 162-172 differed from other sequences at one to five base positions, the sequence 5'-TCTTTCTTT-3' at positions 176-184 differed from other sequences at two to five base positions, and the sequence $5^{\prime}$ GTCAAAAC- $3^{\prime}$ at positions 822-829 differed from the sequences in other phytoplasmas at one to four base positions.

\section{DISCUSSION}

This communication provides evidence that a previously undescribed phytoplasmal organism is associated with hibiscus witches' broom disease in Brazil. Amplification of phytoplasma-characteristic DNA fragments from diseased plants indicated the association of a phytoplasma with the disease, and the presence in the $16 \mathrm{~S}$ rDNA of sequences unique to phytoplasmas established that the organism was a phytoplasma. The data also indicated that this phytoplasma is unique among all previously described phytoplasmas. The hibiscus witches' broom phytoplasma was distinct on the basis of RFLP analysis of amplified rRNA operon sequences, analysis of nucleotide sequence data for sequence similarities and putative restriction sites in the DNA, and phylogenetic analysis of $16 \mathrm{~S}$ rDNA sequences by using the neighbour-joining method. On the basis of comparisons of the RFLP patterns of 16S rDNA from hibiscus witches' broom phytoplasma with the patterns of reference strains used in this study and with results reported elsewhere (Lee et al., 1993, 1998; Davis et al., 1997; Jomantiene et al., 1998a, b; Montano et al., 2000), we classified hibiscus witches' broom phytoplasma as a member of a new 16S rRNA gene group, designated group $16 \mathrm{SrXV}$. Our phylogenetic analysis of $16 \mathrm{~S}$ rRNA gene sequences indicated that the hibiscus witches' broom phytoplasma forms a distinct subclade, which we have designated subclade xiv and which differs from other phytoplasma subclades.

This and other work (Montano et al., 2000; R. E. Davis \& E. L. Dally, unpublished) has indicated the presence, in South America, of several phytoplasma lineages not found in other regions. These findings are consistent with the concept that a unique ecology and geographic separation provided conditions favourable for phytoplasmal divergence from phytoplasma lineages in other regions of the world. Thus, the ecology and geographical location of Brazil may have provided conditions that favoured evolution of the distinct hibiscus witches' broom phytoplasma.

Each phytoplasmal 16S rRNA RFLP group or subgroup corresponds to a distinct subclade within the monophyletic clade that represents all phytoplasma organisms which descended from an Acholeplasmalike ancestor within the class Mollicutes (Gundersen et al., 1994; Lee et al., 1998; White et al., 1998). The 
taxonomic rank of species has been proposed for each of the several distinct subclades (Gundersen et al., 1994). Our data clearly establish placement of the hibiscus witches' broom phytoplasma within a distinct subclade, namely subclade xiv. In addition, our phylogenetic analysis confirmed the conclusion, based on an RFLP analysis of rDNA, that the hibiscus witches' broom phytoplasma represents a 16S rRNA group that is distinct from those of other phytoplasmas. The phylogeny inferred from the phylogenetic tree indicates that the hibiscus witches' broom phytoplasma represents a lineage distinct from those of other phytoplasmas.

It has not been possible to obtain any phytoplasmas in axenic culture, but a means of describing and naming putative taxa such as the phytoplasmas has been described (Murray \& Schleifer, 1994). Thus, to facilitate reference to unique phytoplasmal lineages and to have names by which distinct phytoplasmas can be known, the convention of 'Candidatus Phytoplasma species' has been adopted. The names 'Candidatus Phytoplasma aurantifolia', 'Candidatus Phytoplasma australiense', 'Candidatus Phytoplasma australasia', 'Candidatus Phytoplasma japonicum' and 'Candidatus Phytoplasma fraxini' have been proposed for phytoplasmas associated with different diseases of plants (Zreik et al., 1995; Davis et al., 1997; White et al., 1998; Griffiths et al., 1999; Sawayanagi et al., 1999). We propose that the hibiscus witches' broom phytoplasma be designated a new, distinct 'Candidatus' species, 'Candidatus Phytoplasma brasiliense', with the following description: 'Candidatus Phytoplasma brasiliense' [(Mollicutes) NC; NA; O; NAS (GenBank no. AF147708); oligonucleotide sequences of unique regions of the 16S rRNA gene are 5'-GAAAAAGAAAG-3', 5'-TCTTTCTTT-3', 5'-CAG-3', 5'-ACTTTG-3' and 5'-GTCAAAAC-3'; $\mathrm{P}$ (Hibiscus, phloem); M].

\section{ACKNOWLEDGEMENTS}

This work was presented as part of the doctorate thesis of H. G. M. Work by H.G. M. and P. S. T. B. was supported by a fellowship from the National Research Council of Brazil (CNPq). H. G. M. was a visiting scientist in the Molecular Plant Pathology Laboratory, USDA-ARS (Beltsville, MD) under sponsorship by the CNPq. We gratefully acknowledge Jadier de Oliveira Cunha Júnior and Ana Rosa Figueiredo for assistance with DNA extraction, Kristi Bottner for technical assistance with DNA cloning and sequencing, and James Plaskowitz for help with illustrations.

\section{REFERENCES}

Barros, T. S. L., Kitajima, E. W. \& Resende, R. O. (1997). Classification of phytoplasmas found in Brasil using restriction fragment length polymorphism. Fitopatol Bras 22, 346.

Barros, T. S. L., Kitajima, E. W. \& Resende, R. O. (1998). Divergence of Brasilian phytoplasmas based on analysis of $16 \mathrm{~S}$ rDNA. Fitopatol Bras 23, 459-465.

Blossfeld, H. (1984). A utilização de plantas no paisagismo do
Brasil. In Anais do IV Congresso Brasileiro de Floricultura e Plantas Ornamentais, pp. 49-59

Davis, R. E. (1995). Fitoplasmas: fitopatógenos procarióticos sem parede celular, habitantes de floema e transmitidos por artrópodes. Rev Anu Patol Plant 3, 1-27.

Davis, R. E., Dally, E. L., Gundersen, D. E., Lee, I.-M. \& Habili, N. (1997). 'Candidatus Phytoplasma australiense', a new phytoplasma taxon associated with Australian grapevine yellows. Int $J$ Syst Bacteriol 47, 262-269.

Davis, R. E., Jomantiene, R., Dally, E. L. \& Wolf, T. K. (1998). Phytoplasmas associated with grapevine yellows in Virginia belong to group 16SrI, subgroup A (tomato big bud phytoplasma subgroup), and group 16SrIII, new subgroup I. Vitis 37, 131-137.

Deng, S. \& Hiruki, D. (1991). Amplification of 16S rRNA genes from culturable and nonculturable mollicutes. $J$ Microbiol Methods 14, 53-61.

Griffiths, H. M., Sinclair, W. A., Smart, C. D. \& Davis, R. E. (1999). The phytoplasma associated with ash yellows and lilac witches'broom: 'Candidatus Phytoplasma fraxini'. Int J Syst Bacteriol 49, 1605-1614.

Gundersen, D. E. \& Lee, I.-M. (1996). Ultrasensitive detection of phytoplasmas by nested-PCR assays using two universal primer pairs. Phytopathol Mediterr 35, 144-151.

Gundersen, D. E., Lee, I.-M., Rehner, S. A., Davis, R. E. \& Kingsbury, D. T. (1994). Phylogeny of mycoplasmalike organisms (Phytoplasmas): a basis for their classification. $J$ Bacteriol 176, 5244-5254.

Hiruki, C. (1987). Witches'-broom of Hibiscus heterophyllus, a mycoplasma disease occurring in Australia. Ann Phytopathol Soc Jpn 53, 1-6.

Jomantiene, R., Davis, R. E., Dally, E. L., Maas, J. L. \& Postman, J. D. (1998a). The distinctive morphology of 'Fragaria multicipita' is due to phytoplasma. HortScience 33, 1069-1072

Jomantiene, R., Davis, R. E., Maas, J. L. \& Dally, E. L. (1998b). Classification of new phytoplasmas associated with diseases of strawberry in Florida, based on analysis of 16S rRNA and ribosomal protein gene operon sequences. Int $J$ Syst Bacteriol 48, 269-277.

Kitajima, E. W. (1994). Enfermidades de plantas associadas a organismos do tipo micoplasma. Rev Anu Patol Plant 2, 153-174.

Kitajima, E. W., Ribeiro, R. L. D., Lin, M. R., Ribeiro, M. I. S. D., Kimura, O., Costa, C. L. \& Pimentel, J. P. (1984). Lista comentada de vírus e organismos do tipo micoplasma em plantas cultivadas esilvestres do Estado do Rio de Janeiro. Fitopatol Bras 9, 607-625.

Lee, I.-M., Hammond, R. W., Davis, R. E. \& Gundersen, D. E. (1993). Universal amplification and analysis of pathogen $16 \mathrm{~S}$ rDNA for classification and identification of mycoplasmalike organisms. Phytopathology 83, 834-842.

Lee, I.-M., Gundersen-Rindal, D. E., Davis, R. E. \& Bartoszyk, I. M. (1998). Revised classification scheme of phytoplasmas based on RFLP analyses of 16S rRNA and ribosomal protein gene sequences. Int J Syst Bacteriol 48, 1153-1169.

Lim, P.-O. \& Sears, B. B. (1989). 16S rRNA sequence indicates that plant-pathogenic mycoplasmalike organisms are evolutionarily distinct from animal mycoplasmas. J Bacteriol 171, 5901-5906.

Montano, H. G. \& Brioso, P. S. T. (1997). Detection of witches'broom phytoplasmas infecting Hibiscus rosa-sinensis, in Rio de 
Janeiro state, by polymerase chain reaction (PCR). In Resumos da XXVI Reunião Anual da Sociedade Brasileira de Bioquímica e Biologia Molecular, p. 74.

Montano, H. G., Davis, R. E., Dally, E. L., Pimentel, J. P. \& Brioso, P. S. T. (2000). Identification and phylogenetic analysis of a new phytoplasma from diseased chayote in Brazil. Plant Dis 84, 429-436.

Murray, R. G. E. \& Schleifer, K. H. (1994). Taxonomic notes: a proposal for recording the properties of putative taxa of prokaryotes. Int J Syst Bacteriol 44, 174-176.

Namba, S., Oyaizu, H., Kato, S., Iwanami, S. \& Tsuchizaki, T. (1993). Phylogenetic diversity of phytopathogenic mycoplasmalike organisms. Int J Syst Bacteriol 43, 461-467.

Nei, M. \& Li, W.-H. (1979). Mathematical model for studying genetic variation in terms of restriction endonucleases. Proc Natl Acad Sci U S A 76, 5269-5273.

Padovan, A. C., Gibb, K. S., Daire, X. \& Boudon-Padieu, E. (1996). A comparison of the phytoplasma associated with Australian grapevine yellows to other phytoplasmas in grapevine. Vitis $\mathbf{3 5}$, 189-194.

Page, R. D. (1996). TREEVIEW: an application to display phylogenetic trees on personal computers. CABIOS 12, 357-358.

Penna, L. de A. (1983). Jardins, Hortas. Um guia prático e completo de jardinagem e horticultura. Editora Artenova, 15a Edição.

Sawayanagi, T., Horikoshi, N., Kanehira, T., Shinohara, M., Bertaccini, A., Cousin, M.-T., Hiruki, C. \& Namba, S. (1999). 'Candidatus Phytoplasma japonicum', a new phytoplasma taxon associated with Japanese Hydrangea phyllody. Int J Syst Bacteriol 49, 1275-1285.

Schneider, B., Cousin, M. T., Klinkong, S. \& Seemüller, E. (1995a). Taxonomic relatedness and phylogenetic positions of phytoplasmas associated with diseases of faba bean, sunnhemp, sesame, soybean, and eggplant. Z Pflanzenkr Pflanzenschutz 102, 225-232.

Schneider, B., Seemüller, E., Smart, C. D. \& Kirkpatrick, B. (1995b). Phylogenetic classification of plant pathogenic mycoplasmalike organisms or phytoplasmas, In Molecular and Diagnostic Procedures in Mycoplasmology, vol. 1, pp. 369-380. Edited by S. Razin \& J. G. Tully. San Diego, CA: Academic Press.
Seemüller, E., Schneider, B., Maurer, R. \& 8 other authors. (1994). Phylogenetic classification of phytopathogenic mollicutes by sequence analysis of $16 \mathrm{~S}$ ribosomal DNA. Int $J$ Syst Bacteriol 44, 440-446.

Seemüller, E., Marcone, C., Lauer, U., Ragozzino, A. \& Göschl, M. (1998). Current status of molecular classification of the phytoplasmas. J Plant Pathol 80, 3-26.

Stackebrandt, E. \& Goebel, B. M. (1994). Taxonomic note: a place for DNA-DNA reassociation and 16S rRNA sequence analysis in the present species definition in bacteriology. Int $J$ Syst Bacteriol 44, 846-849.

Staniulis, J., Davis, R. E., Jomantiene, R., Kalvelyte, A. \& Dally, E. L. (2000). Single and mixed phytoplasma infections in phyllody- and dwarf-diseased clover plants in Lithuania. Plant Dis 84, 1061-1066.

Thompson, J. D., Gibson, T. J., Plewniak, F., Jeanmougin, F. \& Higgins, D. G. (1997). The CLUSTAL X windows interface: flexible strategies for multiple sequence alignment aided by quality analysis tools. Nucleic Acids Res 25, 4876-4882.

Tymon, A. M., Jones, P. \& Harrison, N. (1998). Phylogenetic relationships of coconut phytoplasmas and the development of specific oligonucleotide PCR primers. Ann Appl Biol 132, 437-452.

Vicente, M., Caner, J. \& July, J. R. (1974). Corpúsculos do tipo micoplasma em Hibiscus rosa sinensis. Arq Inst Biol São Paulo 41, 53-58.

Weisburg, W. G., Tully, J. G., Rose, D. L. \& 11 other authors. (1989). A phylogenetic analysis of the mycoplasmas: basis for their classification. $J$ Bacteriol 171, 6455-6467.

White, D. T., Blackwall, L. L., Scott, P. T. \& Walsh, K. B. (1998). Phylogenetic positions of phytoplasmas associated with dieback, yellow crinkle and mosaic diseases of papaya, and their proposed inclusion in 'Candidatus Phytoplasma australiense' and a new taxon, 'Candidatus Phytoplasma australasia'. Int $J$ Syst Bacteriol 48, 941-951.

Zreik, L., Carle, P., Bové, J. M. \& Garnier, M. (1995). Characterization of the mycoplasmalike organism associated with witches'-broom disease of lime and proposition of a Candidatus taxon for the organism, 'Candidatus Phytoplasma aurantifolia'. Int J Syst Bacteriol 45, 449-453. 